\title{
$\begin{array}{ll}\text { Research Square } & \begin{array}{l}\text { Preprints are preliminary reports that have not undergone peer review. } \\ \text { They should not be considered conclusive, used to inform clinical practice, } \\ \text { or referenced by the media as validated information. }\end{array}\end{array}$
}

\section{High Frequency of CTNNB1 Mutation in Low Grade Fetal Adenocarcinoma of the Lung: Two Case Series and Literature Review}

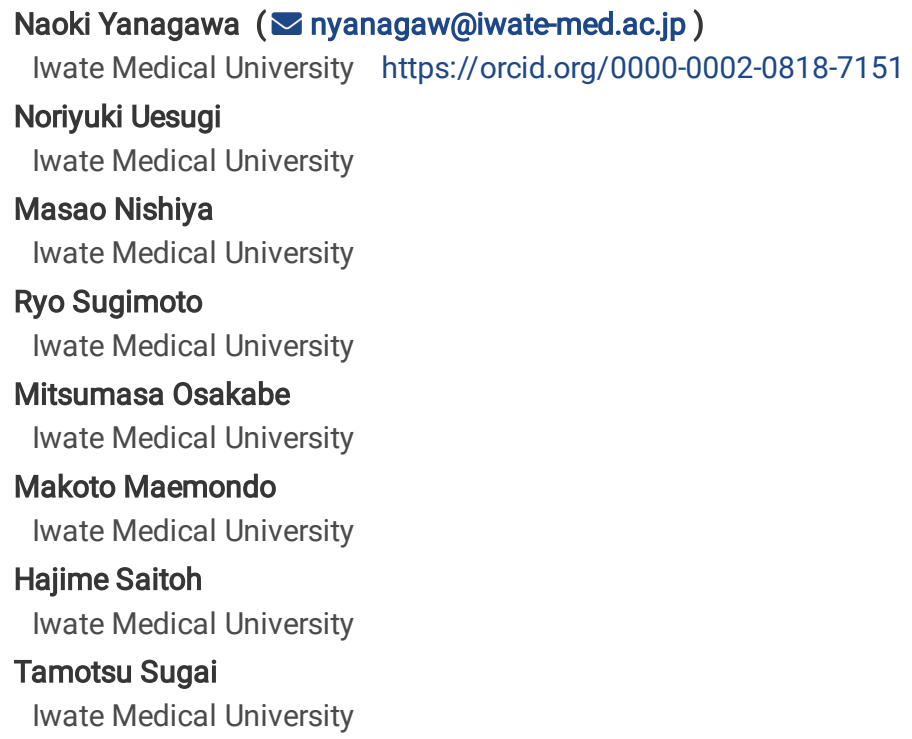

License: (c) (1) This work is licensed under a Creative Commons Attribution 4.0 International License. Read Full License 


\section{Abstract \\ Background}

Low-grade fetal adenocarcinoma of the lung (L-FLAC) is a rare pulmonary tumor resembling fetal lung histologically. Due to its rarity, there is limited information about L-FLAC pathogenesis and biological characteristics. Here, we describe two cases of L-FLAC treated at our hospital and summarize L-FLAC cases reported in the literature.

\section{Case presentation:}

We examined one woman and one man who were 30-years-old and 67-years-old, respectively. Histologically, tumor tissue from both cases had a complex glandular component with clear cuboidal and columnar cells that resembled histological features of fetal lung. In some areas, squamous morules were prominent. Immunohistochemically, nuclear/cytoplasmic expression of $\beta$-catenin was detected in both cases. Mutation analysis revealed a CTNNB1 mutation in both cases and a DICER1 mutation in 1 case. No mutations in EGFR, BRAF, KRAS, PIK3CA mutation were found.

\section{Conclusions}

L-FLAC showed a high frequency of CTNNB1 mutation and low frequency of EGFR, KRAS, BRAF and PIK3CA mutation in our examined cases and in previous studies. This rare tumor has unique clinicopathological characteristics with specific genetic aberrations involving the Wnt pathway. These results provide a molecular basis for development of new therapies to treat these tumors.

\section{Introduction}

Fetal lung adenocarcinoma (FLAC) is an extremely rare lung cancer that accounts for only $0.1-0.5 \%$ of all pulmonary neoplasms [1, 2]. FLACs are divided into two subtypes: low-grade FLAC (L-FLAC) and high-grade FLAC (H-FLAC) [1, 2]. These subtypes show distinct clinicopathological characteristics, biological behavior and outcomes. The incidence of L-FLAC is lower than that for H-FLAC. Zhang et al. reported that the prevalence of L-FLAC and H-FLAC was $0.32 \%$ and $0.54 \%$, respectively, in Chinese patients [3]. Due to its rarity, information about the pathogenesis and biological characteristics of L-FLAC is limited. Here we describe two cases of L-FLAC.

\section{Case Presentations}

Case 1 was a 30-year-old female who visited our hospital for further examination of an abnormal chest shadow detected during a checkup. The patient had no medical history and never smoked. A computed tomography scan revealed a nodular lesion $30 \mathrm{~mm}$ in diameter in the peripheral area of the right upper lobe. On biopsy examination, the lesion was diagnosed as adenocarcinoma and right upper lobectomy with hilar and mediastinal lymph node dissection was performed. Case 2 was a 67-year-old male who came to ourhospital for a detailed examination of an abnormal chest shadow detected during a checkup. This individual smoked 20 cigarettes a day for 47 years. A nodular lesion in the peripheral area of the right lower lobe was detected by a chest CT scan. This lesion was diagnosed as adenocarcinoma by intraoperative pathological examination and right lower lobectomy with hilar and mediastinal lymph node dissection was performed.

\section{Histopathological and immunohistochemical findings}

In both cases, tumor tissue was composed of complex glands and tubules with scant stroma at low magnification (Figure 1a and 1b). At high power magnification, cuboidal and columnar cells could be observed that were arranged in complex gland-like structures with supranuclear or subnuclear vacuoles. (Figure 1c and 1d). In some areas, squamous morules were prominent (Figure 1e and 1f). Diastase pretreatment periodic acid Schiff reaction demonstrated glycogen within the cytoplasm of the tumor cells. Immunohistochemical study was performed using an autoimmunostaining system (Dako EnVision System, Dako, CA, USA). For both cases we detected membrane and nuclear expression of CTNNB1 ( $\beta$ catenin) (clone 14; Becton Dickinson) (Figure 2a and 2b) as well as expression of cytokeratin 7 (OV-TL 12/30, Dako), TTF-1 (8G7G3/1, Dako) (Figure 2c and 2d), Napsin A (IP64, Novocastra), Synaptophysin (focal) (SY38, Dako), chromogranin A (focal) (DAK-A3, Dako), and CD56 (NCAM) (1B6, Dako). SALL4 expression (6E3, Sigma-Aldrich) was detected in case 1 (Figure 2e and 2f). On the other hand, overexpression of p53 (D0-7, Novocastra) and expression of PD-L1 (22c3, Dako) was not observed in either case.

\section{Mutation analysis}

Mutation analysis was performed for CTNNB1, DICER1, KRAS, BRAF and PIK3CA. EGFR mutation testing carried out at the time of diagnosis detected no mutations. We conducted polymerase chain reaction (PCR) followed by Sanger sequencing and pyrosequencing of tissues samples from the two patients. Briefly, DNA from formalin-fixed paraffin-embedded tissues was extracted using TaKaRa DEXPAT (Takara Bio Inc., Shiga, 
Japan). The tumor component on the slides was microdissected to increase the proportion of tumor cells. The PCR products were purified using a NucleoSpin Gel and PCR Clean-up, Mini kit (Marcherey-Nagel, Duren, Germany). Each purified product was directly sequenced using a forward primer and the BigDye Terminator version 3.1 cycle sequencing kit with an ABI 3730 instrument (Applied Biosystems Inc., Foster City, CA). Mutation analyses of CTNNB1 (exon 3), DICER1 (exon 24 and 25) and PIK3CA (exons 9 and 20) were performed. Mutation analyses of BRAF (exon 15) and KRAS (exons 2 and 3) were also performed using a BRAF Pyro Kit and KRAS Pyro Kit (Qiagen, Venlo, Netherlands), respectively, in real-time using pyrosequencing technology with the PyroMark Q24 System (Qiagen). Mutation of CTNNB1 was detected for both cases. Case 1 and Case 2 had the missense mutation c98C>T (p.S33F) (Figure 3a) and c110C>T (p.S37F) (Figure 3b), respectively. Case 2 also had a missense mutation in DICER1: c.5126A>G (p.D1709G) (Figure 3c). No mutation in BRAF, KRAS and PIK3CA was detected.

\section{Discussion}

FLAC is an adenocarcinoma resembling developing fetal lung in its pseudoglandular stage (8-16 weeks of gestation)[2][4]. Histopathologically, FLAC comprises complex, branch-forming tubular glands lined by glycogen-rich, non-ciliated columnar or cuboidal cells. The cells have a clear cytoplasm; large vesicular nuclei are seen in addition to supranuclear or subnuclear vacuoles. The malignant glands are densely packed and situated within loose to moderate cellular fibroblastic stroma [1, 2]. Due to their distinct clinicopathological characteristics, biological behavior and outcome, FLACs have been classified into L-FLAC and H-FLAC. L-FLAC shows low nuclear atypia, prominent morule organization and pure histological pattern [1-3]. In contrast, H-FLAC displays prominent nuclear atypia and nucleoli, high mitotic rate and necrosis [2]. H-FLAC includes fetal morphology ranging between $51 \%$ and $100 \%$ and is often accompanied by other conventional types of lung adenocarcinoma [4, 5]. Our two cases showed typical L-FLAC morphology.

In addition to distinct histopathological patterns, L-FLAC and H-FLAC demonstrate different immunohistochemical staining and genetic alterations. To date, aberrant $\beta$-catenin nuclear expression/cytoplasmic staining and/or CTNNB1 mutation have been frequently observed in LFLAC. Meanwhile, p53 protein overexpression is not observed in L-FLAC and mutations in EGFR, KRAS, BRAF and PIK3CA occur at very low frequency relative to both $\mathrm{H}$-FLAC and conventional lung adenocarcinoma [1, 6-8]. Our two cases also showed the same features. Studies reporting clinicopathological characteristics of L-FLAC with genetic analysis are summarized in Table 1 [6-12]. To date, 21 L-FLACs, including the two in our study, have been reported. All showed $\beta$-catenin nuclear/cytoplasmic staining. CTNNB1 mutation was detected in 17/21 (80.9\%) L-

FLACs. This result supports a close relationship between $\beta$-catenin nuclear/cytoplasmic staining and CTNNB1 mutation. $\beta$-catenin is a key protein in the Wnt signaling pathway, which plays important roles during embryogenesis. Altered Wnt signaling activity can lead to tumor formation [3]. CTNNB1 exon 3 mutations are associated with decreased degradation of $\beta$-catenin that then accumulates in the cytoplasm and subsequently translocates to the nucleus. These events can reasonably explain the immunophenotypic features of $\beta$-catenin staining in L-FLAC [8, 9]. Wntactivating mutations of CTNNB1 that lead to the abnormal induction and/or continued progenitor proliferation might be the intrinsic drivers of $\mathrm{L}$ FLAC [8]. In contrast, CTNNB1 mutations are rarely reported in lung cancers including H-FLAC. Indeed, studies by Kim et al. [13] and Zhou et al. reported that the prevalence of CTNNB1 mutations was 3.9\% (9/230) and 5.3\% (30/564), respectively, in lung adenocarcinoma. Suzuki et al. detected CTNNB1 mutations in 2/16 patients with H-FLAC [15]. Therefore, the high prevalence of CTNNB1 mutation is a hallmark of L-FLAC and could serve as a diagnostic marker. 
Table 1

Clinicopathological characteristics of L-FLAC with genetic analysis in the present study and literature review

\begin{tabular}{|c|c|c|c|c|c|c|c|c|c|}
\hline Author & $\begin{array}{l}\text { Number } \\
\text { of } \\
\text { examined } \\
\text { cases }\end{array}$ & $\begin{array}{l}\text { Number } \\
\text { of cases } \\
\text { with } \\
\text { mutation }\end{array}$ & Age/Sex & Size & Stage & $\begin{array}{l}\text { Smoking } \\
\text { status }\end{array}$ & $\begin{array}{l}\beta \text {-Catenin } \\
\text { immunohistochemistry }\end{array}$ & Genetic Mutation & $\begin{array}{l}\text { Outcome } \\
\text { (month) }\end{array}$ \\
\hline \multirow{2}{*}{$\begin{array}{l}\text { Nakatani } \\
\text { et al. } \\
(2002)\end{array}$} & 5 & 2 & ND & ND & ND & ND & $\begin{array}{l}\text { Nuclear/Cytoplasmic } \\
\text { expression }\end{array}$ & $\begin{array}{l}\text { CTNNB1 (exon 3, } \\
\text { c.101G>T, p.G34V) }\end{array}$ & ND \\
\hline & & & ND & ND & ND & ND & $\begin{array}{l}\text { Nuclear/Cytoplasmic } \\
\text { expression }\end{array}$ & $\begin{array}{l}\text { CTNNB1 (exon 3, } \\
\text { c.110G>T, p.G34V) }\end{array}$ & ND \\
\hline \multirow[t]{3}{*}{$\begin{array}{l}\text { Sekine et } \\
\text { al. (2003) }\end{array}$} & 3 & 3 & $32 / F$ & $\begin{array}{l}32 \\
\mathrm{~mm}\end{array}$ & ND & ND & $\begin{array}{l}\text { Nuclear/Cytoplasmic } \\
\text { expression }\end{array}$ & $\begin{array}{l}\text { CTNNB1 (exon 3, } \\
\text { c.94G>T, p.A32T) }\end{array}$ & ND \\
\hline & & & $22 / F$ & $\begin{array}{l}28 \\
\mathrm{~mm}\end{array}$ & ND & ND & $\begin{array}{l}\text { Nuclear/Cytoplasmic } \\
\text { expression }\end{array}$ & $\begin{array}{l}\text { CTNNB1 (exon 3, } \\
\text { c.98C>G, p.S33C) }\end{array}$ & ND \\
\hline & & & $23 / F$ & $\begin{array}{l}30 \\
\mathrm{~mm}\end{array}$ & ND & ND & $\begin{array}{l}\text { Nuclear/Cytoplasmic } \\
\text { expression }\end{array}$ & $\begin{array}{l}\text { CTNNB1 (exon 3, } \\
\text { c. } 110 \mathrm{C}>\mathrm{G}, \text { p.S37C) }\end{array}$ & ND \\
\hline $\begin{array}{l}\text { de Kock et } \\
\text { al. (2016) }\end{array}$ & 1 & 1 & $16 / F$ & $\begin{array}{l}67 \\
\mathrm{~mm}\end{array}$ & ND & ND & $\begin{array}{l}\text { Nuclear/Cytoplasmic } \\
\text { expression }\end{array}$ & $\begin{array}{l}\text { CTNNB1 (exon 3, } \\
\text { c.98C>G, p.S33C), } \\
\text { DICER1 (exon 21, } \\
\text { c.3540C>A, } \\
\text { p.Tyr1180; exon 24, } \\
\text { c.5127T>A, } \\
\text { p.D1709G) }\end{array}$ & ND \\
\hline \multirow[t]{2}{*}{$\begin{array}{l}\text { Fu et al. } \\
(2018)\end{array}$} & 2 & 2 & $31 / M$ & $\begin{array}{l}30 \\
\mathrm{~mm}\end{array}$ & ND & Yes & $\begin{array}{l}\text { Nuclear/Cytoplasmic } \\
\text { expression }\end{array}$ & $\begin{array}{l}\text { CTNNB1 (exon 3, } \\
\text { c.110C>A, p.S37Y), } \\
\text { BRCA2 (exon 10, } \\
\text { c.1871C>T, p.C624V), } \\
\text { TSC2 (exon 12, } \\
\text { c.1222T>G, p.F408V) }\end{array}$ & ND \\
\hline & & & $21 / M$ & $\begin{array}{l}58 \\
\mathrm{~mm}\end{array}$ & ND & No & $\begin{array}{l}\text { Nuclear/Cytoplasmic } \\
\text { expression }\end{array}$ & $\begin{array}{l}\text { CTNNB1 (exon 3, } \\
\text { c.110C>G, p.S37C), } \\
\text { DDR2 (p.E499) }\end{array}$ & ND \\
\hline $\begin{array}{l}\text { Liu et al. } \\
(2020)\end{array}$ & 1 & 1 & $39 / F$ & $\begin{array}{l}25 \\
\mathrm{~mm}\end{array}$ & IA & No & $\begin{array}{l}\text { Nuclear/Cytoplasmic } \\
\text { expression }\end{array}$ & $\begin{array}{l}\text { CTNNB1 (exon 3, } \\
\text { c.98C>G, p.S33C), } \\
\text { DICER1 (exon 23, } \\
\text { c.4407_4410delTTCT, } \\
\text { p.S1470Lfs*19; exon } \\
\text { 24, c.5125G>A, } \\
\text { p.D1709N) }\end{array}$ & 17, alive \\
\hline \multirow[t]{4}{*}{$\begin{array}{l}\text { Li et al. } \\
(2021)\end{array}$} & 4 & 4 & $30 / \mathrm{M}$ & ND & IA & No & $\begin{array}{l}\text { Nuclear/Cytoplasmic } \\
\text { expression }\end{array}$ & $\begin{array}{l}\text { CTNNB1 (exon 3, } \\
\text { p.S33C), DICER1 ( } \\
\text { p.Q488*; p.D1709V), } \\
\text { MYCN (p.P44L) }\end{array}$ & $\begin{array}{l}99.5, \\
\text { alive }\end{array}$ \\
\hline & & & $36 / M$ & ND & IB & No & $\begin{array}{l}\text { Nuclear/Cytoplasmic } \\
\text { expression }\end{array}$ & $\begin{array}{l}\text { CTNNB1 (exon 3, } \\
\text { p.S37F), DICER1 } \\
\text { (p.D1810F; } \\
\text { p.A1710del), MYCN } \\
\text { (p.P44L) }\end{array}$ & $\begin{array}{l}36.4 \\
\text { alive }\end{array}$ \\
\hline & & & $48 / M$ & ND & IIB & No & $\begin{array}{l}\text { Nuclear/Cytoplasmic } \\
\text { expression }\end{array}$ & $\begin{array}{l}\text { CTNNB1 (exon 3, } \\
\text { p.D32Y), DICER1 } \\
\text { (p.D1709A) }\end{array}$ & $\begin{array}{l}26.4 \\
\text { alive }\end{array}$ \\
\hline & & & $35 / F$ & ND & IVB & No & $\begin{array}{l}\text { Nuclear/Cytoplasmic } \\
\text { expression }\end{array}$ & $\begin{array}{l}\text { CTNNB1 (exon 3, } \\
\text { p.S37F), DICER1 } \\
\text { (c.5096-1G>T; } \\
\text { p.D1810Y) }\end{array}$ & 3.8, alive \\
\hline $\begin{array}{l}\text { Zhang et } \\
\text { al. }(2021)\end{array}$ & 3 & 2 & $39 / M$ & ND & IB & Yes & $\begin{array}{l}\text { Nuclear/Cytoplasmic } \\
\text { expression }\end{array}$ & $\begin{array}{l}\text { CTNNB1 (exon 3, } \\
\text { c.100G>C, p.G34R), } \\
\text { DICER1 (exon 24, } \\
\text { c.5428A>G, } \\
\text { p.D1810F), MYCN } \\
\text { (exon 2, c.173C>T, } \\
\text { p.T58M) }\end{array}$ & alive \\
\hline
\end{tabular}




\begin{tabular}{|c|c|c|c|c|c|c|c|c|c|}
\hline Author & $\begin{array}{l}\text { Number } \\
\text { of } \\
\text { examined } \\
\text { cases }\end{array}$ & $\begin{array}{l}\text { Number } \\
\text { of cases } \\
\text { with } \\
\text { mutation }\end{array}$ & Age/Sex & Size & Stage & $\begin{array}{l}\text { Smoking } \\
\text { status }\end{array}$ & $\begin{array}{l}\beta \text {-Catenin } \\
\text { immunohistochemistry }\end{array}$ & Genetic Mutation & $\begin{array}{l}\text { Outcome } \\
\text { (month) }\end{array}$ \\
\hline & & & $32 / \mathrm{M}$ & ND & IA & Yes & $\begin{array}{l}\text { Nuclear/Cytoplasmic } \\
\text { expression }\end{array}$ & $\begin{array}{l}\text { CTNNB1 (exon 3, } \\
\text { c.98C>G, p.S33C), } \\
\text { DICER1 (exon 24, } \\
\text { c.5438A>G, } \\
\text { p.E1813G) }\end{array}$ & $\begin{array}{l}11.5 \\
\text { died }\end{array}$ \\
\hline \multirow{2}{*}{$\begin{array}{l}\text { Yanagawa } \\
\text { et al. } \\
\text { (present } \\
\text { study) }\end{array}$} & 2 & 2 & $30 / F$ & $\begin{array}{l}30 \\
\mathrm{~mm}\end{array}$ & IA & No & $\begin{array}{l}\text { Nuclear/Cytoplasmic } \\
\text { expression }\end{array}$ & $\begin{array}{l}\text { CTNNB1 (exon 3, } \\
\text { c98C>T, p. S33F) }\end{array}$ & 36 , alive \\
\hline & & & $67 / M$ & $\begin{array}{l}20 \\
\mathrm{~mm}\end{array}$ & $\mathrm{IA}$ & Yes & $\begin{array}{l}\text { Nuclear/Cytoplasmic } \\
\text { expression }\end{array}$ & $\begin{array}{l}\text { CTNNB1 (exon 3, } \\
\text { c110C>T, p. S37F), } \\
\text { DICER1 (exon 24, } \\
\text { c.5126A>G, } \\
\text { p.D1709G) }\end{array}$ & 42, alive \\
\hline
\end{tabular}

Next generation sequencing for L-FLAC cases allowed the detection of DICER1 mutations $[8,10,11]$. DICER1 encodes an RNase III family endoribonuclease that plays an essential role in microRNA production [16]. Germline inactivation of DICER1 is associated with familial DICER1 syndrome [17]. DICER1 mutation has been observed in different kinds of tumors and could contribute to the development of various cancers [12]. To our knowledge, nine L-FLAC cases, including one of our two cases, have been reported to carry a DICER1 mutation Table 1). All also had a CTNNB1 mutation. Several studies demonstrated that DICER1-related malignancies with a blastomatoid component show SALL4 expression [18, 19]. Liu et al. speculated that SALL4 expression is associated with the DICER1 mutation [11]. However, case 2 in our study that had a DICER1 mutation had no SALL4 expression, whereas case 1 had SALL4 expression, but no DICER1 mutation. Since the number of examined L-FLAC cases remains small, further examination will be needed to determine the incidence of DICER1 mutation in L-FLAC.

In conclusion, L-FLAC showed a high frequency of CTNNB1 mutation and a low frequency of EGFR, KRAS, BRAF and PIK3CA mutation in our two examined cases and in previous studies. This rare tumor has unique clinicopathological characteristics with specific genetic aberrations involving the Wnt pathway. These results suggest that new therapies for L-FLAC could be developed based on these molecular features.

\section{Abbreviations}

FLAC: Fetal lung adenocarcinoma; L-FLAC: Low-grade FLAC; H-FLAC: High-grade FLAC; PCR: Polymerase chain reaction

\section{Declarations}

\section{Acknowledgements}

The authors are grateful for technical assistance from Ms. E. Sugawara and C. Ishikawa. They also thank the members of the Department of Molecular Diagnostic Pathology, Iwate Medical University, for their support.

\section{Funding}

The author(s) received no financial support for the research, authorship, and/or publication of this article.

\section{Availability of data and materials}

The datasets used and/or analyzed during the current study are available from the corresponding author upon reasonable request.

\section{Authors' contributions}

NY and TS: conception and writing of manuscript. NY, MM and HS: collection of clinical data. NY, NU, MN, RS and MO: pathological diagnosis and immunohistochemical analyses. NY and NU: collection of samples for molecular analyses. NY and TS: revision of manuscript. All authors read and approved the final manuscript prior to submission.

\section{Ethics approval and consent to participate}

Not applicable.

\section{Consent for publication}


Written informed consent was obtained from the patients for the publication of this case report.

\section{Competing interests}

The authors declare that they have no competing interests

\section{References}

1. Ricaurte LM, Arrieta O, Zatarain-Barrón ZL, Cardona AF. Comprehensive review of fetal adenocarcinoma of the lung. Lung Cancer Targets Ther [Internet]. 2018;9:57-63. Available from: http://www.ncbi.nlm.nih.gov/pubmed/12065775.

2. WHO Classification of Tumours Editorial Board. Thoracic tumours. Lyon (France): International Agency for Research on Cancer; 2021. (WHO classification of tuours series, 5th ed.; vol. 5). https://publications.iarc.fr/595.

3. Zhang J, Sun J, Liang X-L, Lu J, Luo Y, Liang Z. Differences between low and high grade fetal adenocarcinoma of the lung: a clinicopathological and molecular study. J Thorac Dis [Internet]. 2017;9:2071-8. Available from: http://jtd.amegroups.com/article/view/14528/11898.

4. Suzuki M, Yazawa T, Ota S, Morimoto J, Yoshino I, Yamanaka S, et al. High-grade fetal adenocarcinoma of the lung is a tumour with a fetal phenotype that shows diverse differentiation, including high-grade neuroendocrine carcinoma: A clinicopathological, immunohistochemical and mutational study of 20 cases. Histopathology. 2015;67:806-16.

5. Suzuki M, Nakatani Y, Ito H, Narimatsu H, Yamada K, Yoshioka E, et al. Pulmonary adenocarcinoma with high-grade fetal adenocarcinoma component has a poor prognosis, comparable to that of micropapillary adenocarcinoma. Mod Pathol [Internet]. 2018;31:1404-17. Available from: http://dx.doi.org/10.1038/s41379-018-0057-z.

6. Nakatani Y, Masudo K, Miyagi Y, Inayama Y, Kawano N, Tanaka Y, et al. Aberrant nuclear localization and gene mutation of beta-catenin in low-grade adenocarcinoma of fetal lung type: up-regulation of the Wnt signaling pathway may be a common denominator for the development of tumors that form morules. Mod Pathol [Internet]. 2002;15:617-24. Available from: http://www.ncbi.nlm.nih.gov/pubmed/12065775.

7. Fu Y, Wu Q, Su F, Tang Y, Lin Y, Wang W, et al. Novel gene mutations in well-differentiated fetal adenocarcinoma of the lung in the next generation sequencing era. Lung Cancer [Internet]. 2018;124:1-5. Available from: https://doi.org/10.1016/j.lungcan.2018.07.016.

8. Li Y, Xi S, Yong J, Wu X, Yang X, Wang F, Morphologic, Immunohistochemical, and Genetic Differences Between High-grade and Low-grade Fetal Adenocarcinomas of the Lung. Am J Surg Pathol [Internet]. 2021 Jun 17;Publish Ah(6):390-404. Available from: https://journals.Iww.com/10.1097/PAS.0000000000001744.

9. Sekine S, Shibata T, Matsuno Y, Maeshima A, Ishii G, Sakamoto M, et al. $\beta$-Catenin mutations in pulmonary blastomas: Association with morule formation. J Pathol. 2003;200:214-21.

10. De Kock L, Bah I, Wu Y, Xie M, Priest JR, Foulkes WD. Germline and somatic DICER1 mutations in a well-differentiated fetal adenocarcinoma of the lung. J Thorac Oncol [Internet]. 2016;11:e31-3. Available from: http://dx.doi.org/10.1016/j.jtho.2015.09.012.

11. Liu S, Wang J, Luo X, Li X, Miao Y, Wang L, et al. Coexistence of low-grade fetal adenocarcinoma and adenocarcinoma in situ of the lung harboring different genetic mutations: A case report and review of literature. Onco Targets Ther. 2020;13:6675-80.

12. Zhang S, Yin H, Zhang J, Yang L, Yang G, Jia J, et al. Novel genetic characteristics in low-grade fetal adenocarcinoma of the lung. Thorac Cancer. 2021;(May):1-7.

13. Kim IA, Hur JY, Kim HJ, Park JH, Hwang JJ, Lee SA, et al. Targeted Next-Generation Sequencing Analysis for Recurrence in Early-Stage Lung Adenocarcinoma. Ann Surg Oncol [Internet]. 2021;28:3983-93. Available from: https://doi.org/10.1245/s10434-020-09276-x.

14. Zhou C, Li W, Shao J, Zhao J, Chen C. Analysis of the Clinicopathologic Characteristics of Lung Adenocarcinoma With CTNNB1 Mutation. Front Genet. 2020;10:1-7.

15. Suzuki M, Kasajima R, Yokose T, Ito H, Shimizu E, Hatakeyama S, et al. Comprehensive molecular analysis of genomic profiles and PD-L1 expression in lung adenocarcinoma with a high-grade fetal adenocarcinoma component. Transl Lung Cancer Res. 2021;10:1292-304.

16. Ryan BM, Robles Al, Harris CC. Genetic variation in microRNA networks: The implications for cancer research. Nat Rev Cancer. 2010;10:389402.

17. Kamihara J, Paulson V, Breen MA, Laetsch TW, Rakheja D, Shulman DS, et al. DICER1-associated central nervous system sarcoma in children: comprehensive clinicopathologic and genetic analysis of a newly described rare tumor. Mod Pathol [Internet]. 2020;33:1910-21. Available from: http://dx.doi.org/10.1038/s41379-020-0516-1.

18. Agaimy A, Witkowski L, Stoehr R, Cuenca JCC, González-Muller CA, Brütting A, et al. Malignant teratoid tumor of the thyroid gland: an aggressive primitive multiphenotypic malignancy showing organotypical elements and frequent DICER1 alterations-is the term "thyroblastoma" more appropriate? Virchows Arch. 2020;477:787-98. 
19. McCluggage WG, Apellaniz-Ruiz M, Chong AL, Hanley KZ, Velázquez Vega JE, McVeigh TP, et al. Embryonal Rhabdomyosarcoma of the Ovary and Fallopian Tube: Rare Neoplasms Associated With Germline and Somatic DICER1 Mutations. Am J Surg Pathol. 2020;44:738-47.

\section{Figures}

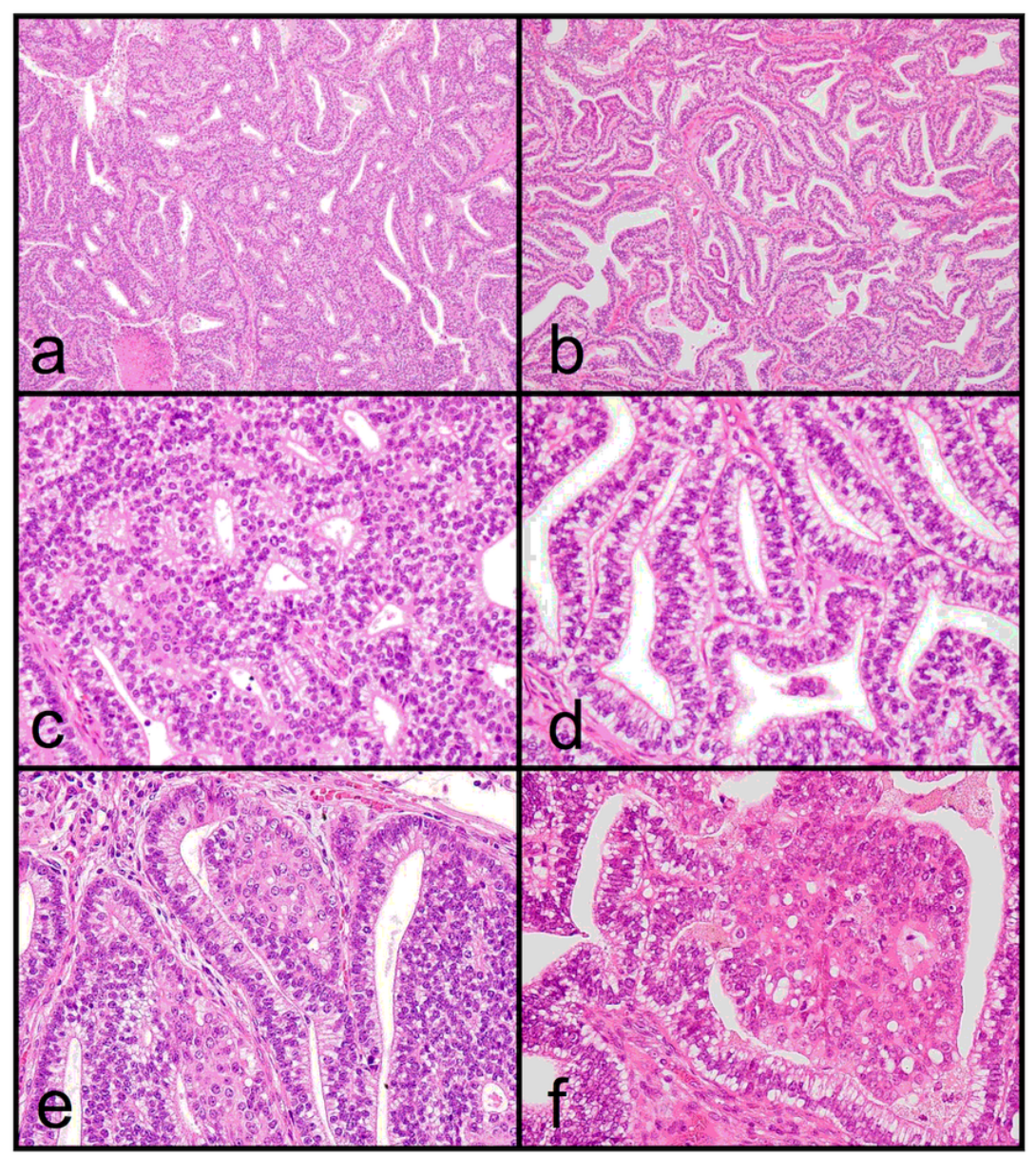

Figure 1

\section{Figure 1}

Representative images of hematoxylin and eosin staining of L-FLAC tumor tissue. The tumor tissue had a complex glandular component with scant stroma ( $a$ and b). Cuboidal and columnar cells with supranuclear or subnuclear vacuoles were present (c and d). A morular component was observed in the tumor tissue (e and f). Case 1 is a, c and e; case 2 is b, $d$ and $f$. 


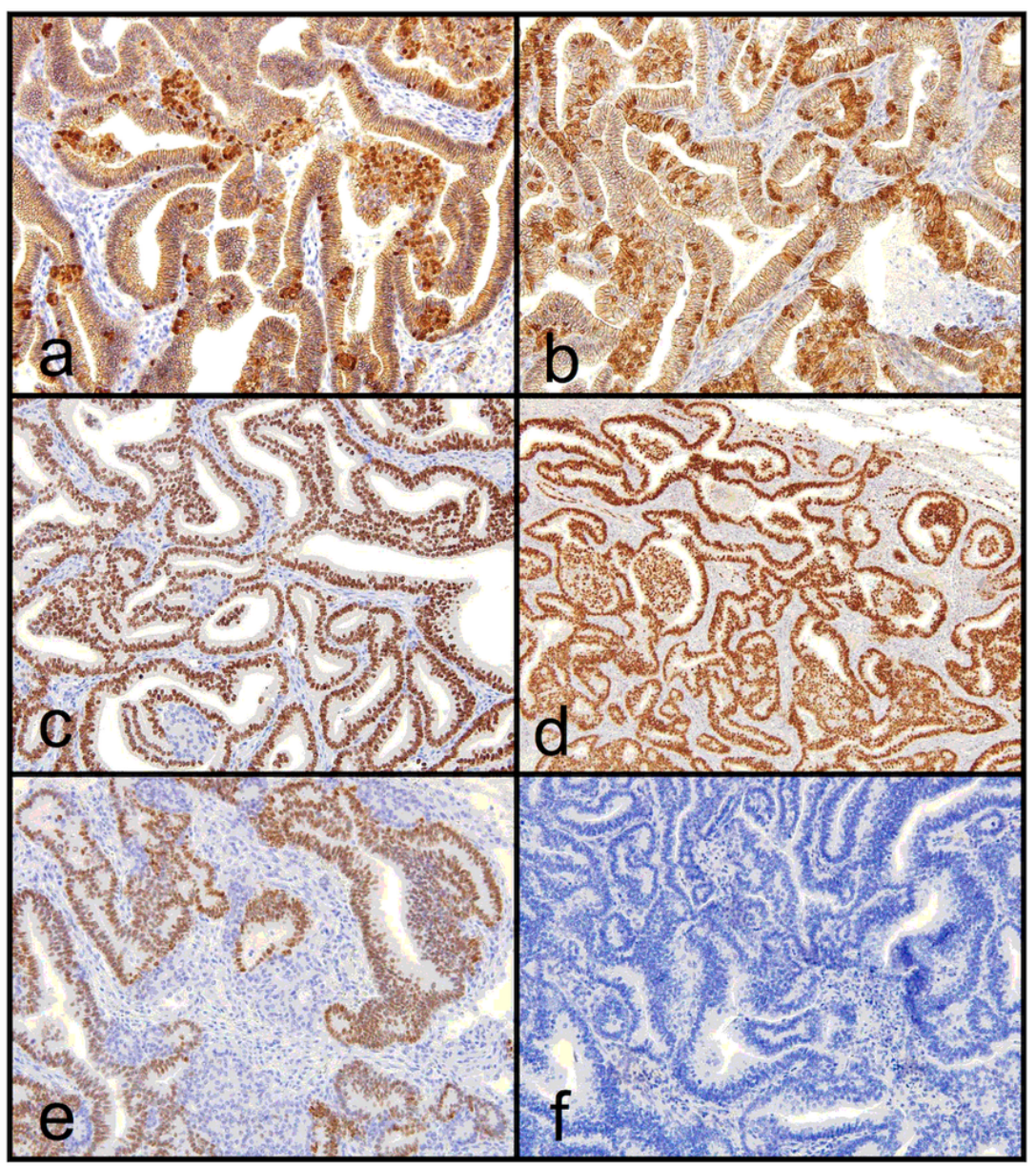

Figure 2

Figure 2

Representative images of immunohistochemical staining of L-FLAC tumor tissue. Both membrane and nuclear expression of CTNNB1 ( $\beta$-catenin) was detected ( $a$ and b). TTF-1 expression was also seen ( $c$ and d). SALL4 expression was seen only for case 1 (e and f). Case 1 is a, c and e; case 2 is $b, d$ and $f$. 

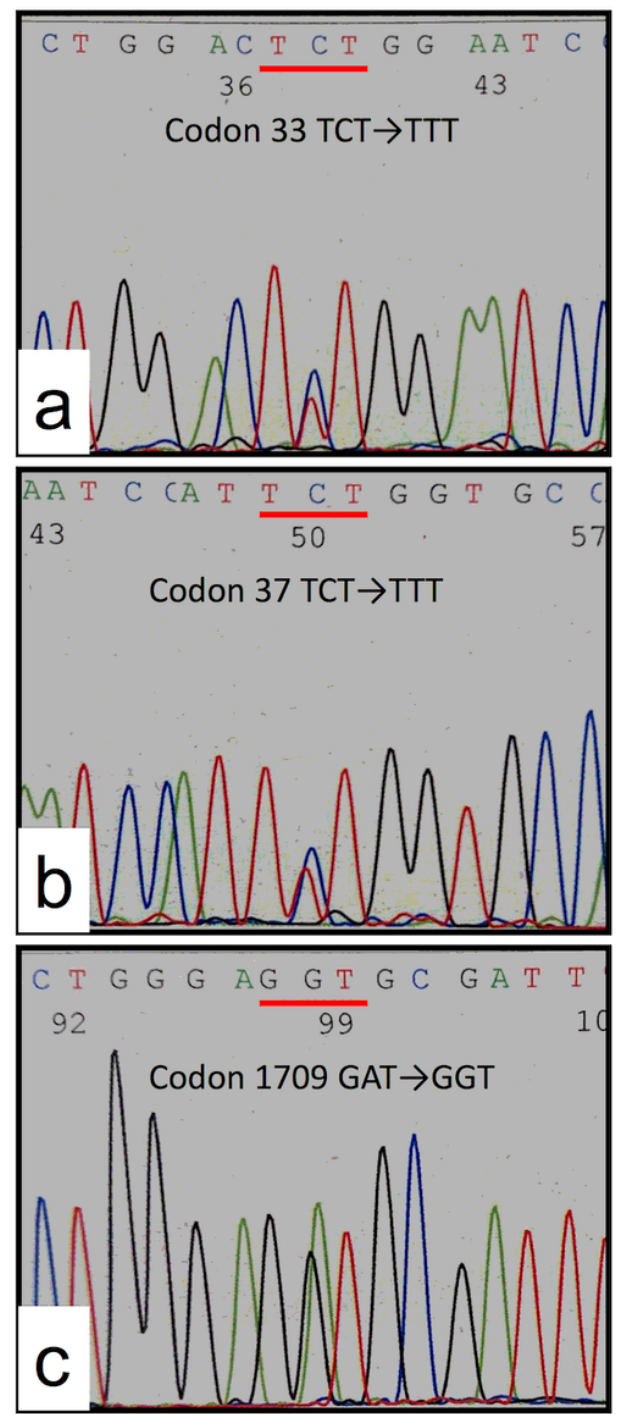

Figure 3

Figure 3

Sequence analysis of CTNNB1 exon 3 and DICER1 exon 24 in L-FLAC. Sequencing chromatograms of CTNNB1 for case 1 (a) and case 2 (b) demonstrated a mixed pattern of wild-type (TCT) and mutant (TTT) peaks at codon 37. The mutation results in an amino acid change of Ser to Phe (S37F). (c) Sequencing chromatogram of DICER1 for case 2 demonstrated a mixed pattern of the wild-type (GAT) and mutant (GGT) peaks at codon 1709 resulting in an amino acid change of Asp to Gly (D1709G). 